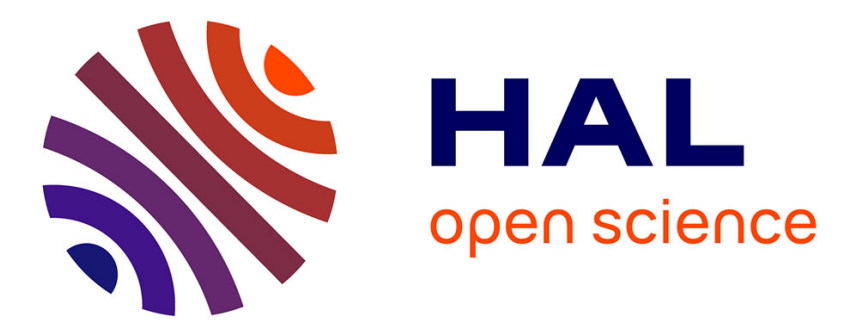

\title{
Solar pyrolysis of heavy metal contaminated biomass for gas fuel production
}

Kuo Zeng, Rui Li, Doan Pham Minh, Elsa Weiss-Hortala, Ange Nzihou, Xiao He, Gilles Flamant

\section{- To cite this version:}

Kuo Zeng, Rui Li, Doan Pham Minh, Elsa Weiss-Hortala, Ange Nzihou, et al.. Solar pyrolysis of heavy metal contaminated biomass for gas fuel production. Energy, 2019, 187 (116016), pp.1-8. 10.1016/j.energy.2019.116016 . hal-02396837

\section{HAL Id: hal-02396837 https://imt-mines-albi.hal.science/hal-02396837}

Submitted on 19 Dec 2019

HAL is a multi-disciplinary open access archive for the deposit and dissemination of scientific research documents, whether they are published or not. The documents may come from teaching and research institutions in France or abroad, or from public or private research centers.
L'archive ouverte pluridisciplinaire HAL, est destinée au dépôt et à la diffusion de documents scientifiques de niveau recherche, publiés ou non, émanant des établissements d'enseignement et de recherche français ou étrangers, des laboratoires publics ou privés. 


\title{
Solar pyrolysis of heavy metal contaminated biomass for gas fuel production
}

\author{
Kuo Zeng ${ }^{\text {a, }}$, Rui Li ${ }^{\text {a }}$, Doan Pham Minh ${ }^{b}$, Elsa Weiss-Hortala ${ }^{b}$, Ange Nzihou ${ }^{b}$, Xiao He ${ }^{\text {, }}$ \\ Gilles Flamant ${ }^{\text {a, }}$ \\ a Processes, Materials and Solar Energy Laboratory, PROMES-CNRS, 7 rue du Four Solaire, 66120, Odeillo Font Romeu, France \\ ${ }^{\mathrm{b}}$ Université de Toulouse, IMT Mines Albi, UMR CNRS 5302, Centre RAPSODEE, Campus Jarlard, F-81013, Albi Cedex 09, France \\ ' State Key Laboratory of Coal Combustion, Huazhong University of Science and Technology, 1037 Luoyu Road, Wuhan, Hubei, 430074, PR China
}

\section{A B S T R A C T}

Article history:

Received 9 July 2019

Received in revised form

17 August 2019

Accepted 25 August 2019

Available online 26 August 2019

Keywords:

Solar pyrolysis

Metal-polluted biomass

Heating parameters

Syngas

\begin{abstract}
The study presented an innovative way to dispose and upgrade heavy metal (HM) contaminated biomass by solar pyrolysis. Pyrolysis of raw and $\mathrm{HM}(\mathrm{Cu}$ and $\mathrm{Ni}$ ) impregnated willow wood was performed in a solar reactor under different temperatures $\left(600,800,1000,1200,1400\right.$ and $\left.1600^{\circ} \mathrm{C}\right)$ and heating rates $(10$ and $50^{\circ} \mathrm{C} / \mathrm{s}$ ). The combined effects of $\mathrm{HM}$ and heating parameters (temperature and heating rates) on solar pyrolysis products were investigated. The results indicated that a threshold temperature of $1000^{\circ} \mathrm{C}$ was required in impregnated willow pyrolysis to make sure copper and nickel catalytic effects on promoting the cracking and reforming reactions of tar. It led to the gas yields from copper or nickel impregnated willow pyrolysis at $1200^{\circ} \mathrm{C}$ increased by $14.76 \%$ and $34.47 \%$, respectively, compared with that from raw willow. In particular, the $\mathrm{H}_{2}$ and $\mathrm{CO}$ production from nickel impregnated willow were higher than those from raw willow (10.30 and $12.16 \mathrm{~mol} / \mathrm{kg}$ of wood versus 6.59 and $8.20 \mathrm{~mol} / \mathrm{kg}$ of wood) in case of fast pyrolysis $\left(50^{\circ} \mathrm{C} / \mathrm{s}\right)$. Under heating rate of $10^{\circ} \mathrm{C} / \mathrm{s}, \mathrm{H}_{2}$ and $\mathrm{CO}$ yields from only nickel impregnated willow increased compared with that from raw willow. Solar pyrolysis of HM contaminated biomass is a promising way to produce valuable syngas.
\end{abstract}

\section{Introduction}

Heavy metals pollution of soil and water has caused severe problem around the world [1]. Phytoextraction is an effective way to decontaminate the soil and water by some plants with high HM enrichment capacity [2]. This kind of plants called hyperaccumulators can absorb HM from polluted soil or water by roots and accumulate them in roots, stems and leaves [3]. HM contents in hyperaccumulators after phytoextraction are hundreds of times higher than the surroundings [4]. For example, the contents of copper and nickel in hyperaccumulators grown on polluted soil can reach $4 \mathrm{~g} / \mathrm{kg}$ and $10 \mathrm{~g} / \mathrm{kg}$ thousands of times higher than contents in polluted soil $[5,6]$. It means that the used biomass for phytoextraction is contaminated by HM. How to dispose of HM contaminated biomass in the right way becomes a critical issue.

Pyrolysis is an effective and economical technology for

\footnotetext{
* Corresponding author.

E-mail address: gilles.flamant@promes.cnrs.fr (G. Flamant).
}

converting HM contaminated biomass into char, gas and oil. The volume of contaminated biomass reduces and valuable pyrolysis products are produced at the same time [7]. Pyrolysis temperature influences HMs distribution in pyrolysis products (char, oil and gas) [3]. HM is then mainly enriched in char product at low temperature pyrolysis, while there is only trace amount of $\mathrm{HM}$ in gas and oil products [8]. More than $98.5 \%$ of the $\mathrm{HMs}(\mathrm{Ni}, \mathrm{Zn}, \mathrm{Cu}, \mathrm{Co}$, and $\mathrm{Cr}$ ) were accumulated in char product obtained from contaminated corn stover at $600^{\circ} \mathrm{C}$ [9-11]. The heating rate also affects HMs distribution in pyrolysis products. It has been found that heavy metals ( $99 \%$ of $\mathrm{Ni}$ and $98 \%$ of $\mathrm{Zn}$ ) were mainly recovered in the char product under slow pyrolysis, whereas most of HMs were retained in the heat transfer medium (white sand) of screw reactor under flash pyrolysis [12,13]. In order to prevent the secondary HM pollution during the use of pyrolysis products (gas and oil), almost all of the researchers try to concentrate HMs in char product through pyrolysis under lower temperature and slower heating rate. However, the environmental risk of HMs loaded char should be addressed before utilization. How to recover or reuse HMs in 
char is also a problem.

High pyrolysis temperature could reduce HMs loaded char toxicity as it favored char aromatization and HMs stabilization [8]. While, the release of HMs to volatiles (gas and oil products) increased with temperature and heating rate, because higher temperature and faster heating rate increased their vapor pressure for enhancing diffusion rates [14]. As the least volatile metals, about $21 \%$ of $\mathrm{Ni}$ and $20 \%$ of $\mathrm{Cu}$ were released to the gas at $850^{\circ} \mathrm{C}$ [15]. A hot-gas filter and condenser can accumulate the HMs from pyrolysis volatiles and greatly reduce their transformation to oil and gas products. Then pyrolysis products (char, gas and oil) contains trace amount of HMs and most of them are recovered from condenser. Pyrolysis products and HMs can be further used in many fields without HMs pollution. However, high temperature pyrolysis process requires high energy consumption with pollution emission. The emission can be eliminated using high temperature process heat provided by a clean energy source. Concentrated solar energy has already been used as the heat source for driving pyrolysis reactions, which upgrades the feedstock into valuable commodities and reduces pollution discharge compared with conventional pyrolysis [16-18]. High temperature and fast heating rate can be easily achieved with solar pyrolysis, offering the possibility to treat HMs contaminated feedstock. In a similar way, more than $99 \%$ of $\mathrm{Zn}$ and $\mathrm{Pb}$ were recovered through carbothermal reduction of electric arc furnace dust at $1124{ }^{\circ} \mathrm{C}$ driven by concentrated solar energy $[19,20]$.

The temperature and heating rate drastically affects the final product distribution and gas composition during solar pyrolysis of raw biomass [16]. The gas product especially $\mathrm{H}_{2}$ and $\mathrm{CO}$ yield significantly increased with temperature (from 600 to $1600^{\circ} \mathrm{C}$ ) and heating rate (from 5 to $50^{\circ} \mathrm{C} / \mathrm{s}$ ) mainly due to the enhanced secondary tar reactions [21]. Besides, temperature and heating rate are known to affect HMs transformation during conventional pyrolysis of contaminated biomass [3]. Many heavy metals such as $\mathrm{Cu}$ and $\mathrm{Ni}$ have catalytic effect on biomass pyrolysis reactions [22]. In HMs contaminated biomass, HMs can work as in-situ catalysts during pyrolysis for enhancing products quality and value [23]. $\mathrm{Cu}$ promoted hemicellulose pyrolysis at low temperature (around $270^{\circ} \mathrm{C}$ ) and restricted the final degradation of cellulose and lignin, which enhanced primary oil (levoglucosan) production [24]. Cu effectively catalyzed the chain-breaking of lignin at $450-600^{\circ} \mathrm{C}$ for producing more C7-C10 compounds [25]. At high pyrolysis temperature of $750{ }^{\circ} \mathrm{C}, \mathrm{Cu}$ (II) was fully turned into $\mathrm{Cu}^{0}$ [1]. Similarly, $\mathrm{Ni}^{0}$ could be produced by the pyrolysis of $\mathrm{Ni}(\mathrm{II})$ polluted wood at temperatures below $500^{\circ} \mathrm{C}$ [26]. The newly formed $\mathrm{Ni}^{0}$ could catalyze the tar conversion into $\mathrm{H}_{2}$ production in the pyrolysis process [27]. Bru et al. found that gas yield obtained from $\mathrm{Ni}$ impregnated biomass at $700{ }^{\circ} \mathrm{C}$ increased from $20.0 \%$ to $33.1 \%$ with $\mathrm{H}_{2}$ yield rising by $260 \%$ compared with those from raw biomass [28]. Ni catalyzed the carboxyl and carbonyl broken for more $\mathrm{CO}_{2}$ formation, while it restricted $\mathrm{CH}_{4}$ release [29]. HMs catalytic activities are greatly affected by their different chemical states, which transform with pyrolysis factors (temperature and heating rate). However, the HMs effect on product distribution during solar pyrolysis is still a question.

To the best of our knowledge, solar pyrolysis of heavy metal contaminated biomass for disposal and improving pyrolysis product properties has not yet been reported. This work presented here puts forward the idea of solar pyrolysis with catalytic reactions. It is expected that under suitable combinations of HMs (type) and pyrolysis conditions (temperature and heating rate), solar pyrolysis tends to produce more valuable gas. This paper focuses on product distribution and gas composition in order to illustrate the catalytic effect. Solar pyrolysis of raw and $\mathrm{HM}(\mathrm{Cu}$ and $\mathrm{Ni})$ impregnated willow wood was investigated under different temperatures $(600$,
$800,1000,1200,1400$ and $\left.1600^{\circ} \mathrm{C}\right)$ and heating rates $\left(10\right.$ and $50^{\circ} \mathrm{C} /$ s).

\section{Experimental}

\subsection{Sample preparation}

The $\mathrm{Cu}$ or Ni impregnated willow was chosen to represent HM contaminated biomass after phytoextraction. $100 \mathrm{~g}$ willow wood particles $(0.5-1 \mathrm{~mm}$ particle size) were impregnated with $1 \mathrm{~L}$ of nickel nitrate aqueous solution or copper nitrate aqueous solution prepared with $\mathrm{Ni}\left(\mathrm{NO}_{3}\right)_{2} \cdot 6 \mathrm{H}_{2} \mathrm{O}$ or $\mathrm{Cu}\left(\mathrm{NO}_{3}\right)_{2} \cdot 6 \mathrm{H}_{2} \mathrm{O}$ (Sigma-Aldrich, $99 \%$ purity). The $\mathrm{Ni}$ or $\mathrm{Cu}$ concentration in the solution was $0.05 \mathrm{wt}$ $\%$. The prepared mixtures were stirred at ambient temperature for $24 \mathrm{~h}$. After that, the impregnated willow particles were then filtered and dried at $60^{\circ} \mathrm{C}$ for $24 \mathrm{~h}$. The resulting $\mathrm{Ni}$ and $\mathrm{Cu}$ concentrations in the impregnated willow were $0.29 \mathrm{~mol} / \mathrm{kg}$ and $0.06 \mathrm{~mol} / \mathrm{kg}$, respectively. Raw willow, Willow with $\mathrm{Ni}$, Willow with $\mathrm{Cu}$ correspond to the non-impregnated wood, $\mathrm{Ni}$ impregnated wood and $\mathrm{Cu}$ impregnated wood as pyrolysis feedstock respectively.

\subsection{Solar pyrolysis experiment}

\subsubsection{Experimental setup}

The experiments were carried out with a vertical solar furnace shown in Fig. 1. The maximum power and flux density are about $1.5 \mathrm{~kW}$ and $12000 \mathrm{~kW} / \mathrm{m}^{2}$, respectively. The experimental setup for wood pyrolysis has already been explained in our previous studies $[18,30]$. It consists in a $25 \mathrm{~m}^{2}$ flat heliostat, a down-facing parabolic mirror ( $2 \mathrm{~m}$ in diameter and $0.85 \mathrm{~m}$ focal length) and a pyrolysis system. The parabolic mirror illuminated by the reflected beam of the heliostat concentrates the solar radiation to the wood pellet set in a graphite crucible. The biomass pellet within graphite crucible is then put in the focus of solar furnace covered by transparent Pyrex reactor swept with the argon flow controlled by a mass flowmeter (Bronkhorst, EL-FLOW ${ }^{\circledR}$ ). Sample temperatures were measured with an optical pyrometer (KLEIBER monochromatic operating at $5.2 \mu \mathrm{m}$ ). A shutter located between the heliostat and the parabola can adjust the incident radiation of the reflected solar beam with PID controller based on the measured sample temperature for reaching the target heating rate and temperature. The size and speed of shutter opening corresponds to its temperature and heating rate control. A 3100 SYNGAS analyzer was employed to online monitor the oxygen content in the reactor.

\subsubsection{Experimental procedure}

Sweep the reactor by argon gas for elimination of air. Set the target temperature and heating rate for pyrolysis on the PID controller. Trigger the PID controller for opening the shutter with the desired openness and speed. The pyrolysis gases were pumped out with a vacuum pump and passed through a condensation train for trapping liquid products. Finally, the gas products were collected in a sampling bag and then injected to GC (SRA Instruments MicroGC 3000) for further analysis.

For investigating combined effects of HM and temperature, Solar pyrolysis experiment were carried out at six different temperatures $\left(600,800,1000,1200,1400\right.$ and $\left.1600^{\circ} \mathrm{C}\right)$ with heating rate of $50^{\circ} \mathrm{C} / \mathrm{s}$. After that, two heating rates $\left(10\right.$ and $\left.50^{\circ} \mathrm{C} / \mathrm{s}\right)$ were investigated at the same temperature of $1200^{\circ} \mathrm{C}$ for determining combined effects of $\mathrm{HM}$ and heating rate. For all experiments, Argon flow rate was $9 \mathrm{NL} / \mathrm{min}$ and plateau temperature duration was $5 \mathrm{~min}$. 


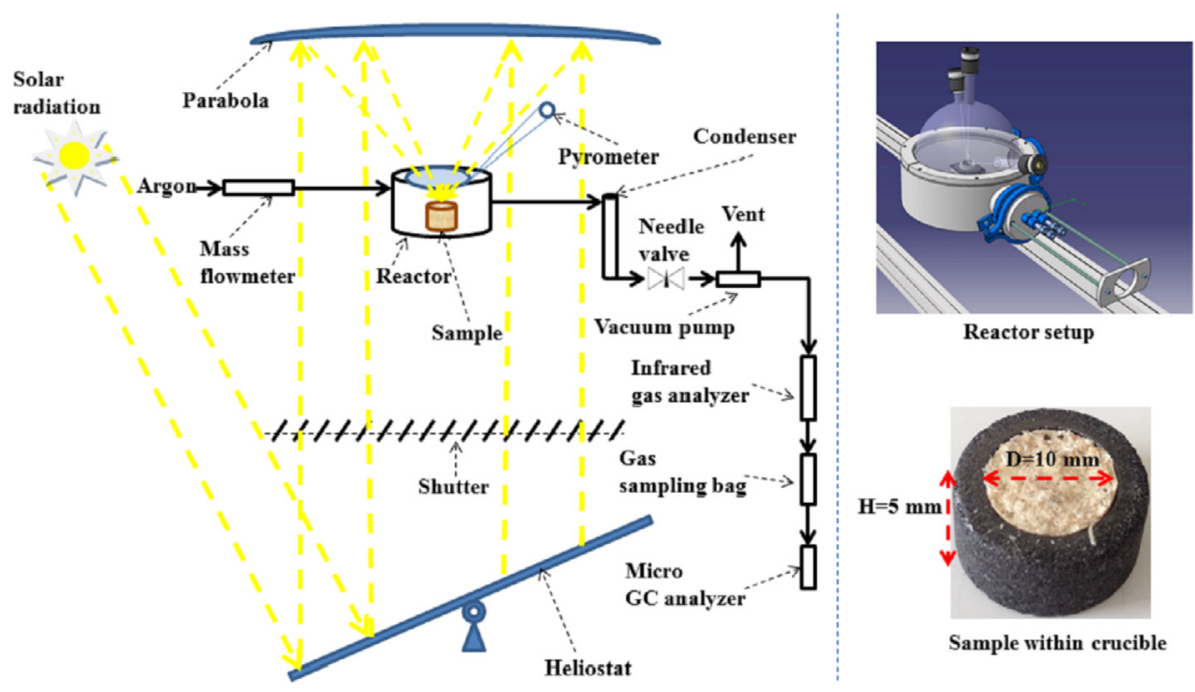

Fig. 1. Schematic of the solar pyrolysis experimental setup.

\subsubsection{Products recovery and characterization}

For each experiment, the sample was weighted before and after pyrolysis to determine the mass of feedstock and char (the solid residue left in the crucible). The gas mass was calculated based on Ideal Gas Law and the gas composition determined by micro-gas chromatography. Char and gas yields were calculated based on dry mass basis. The liquid yield was then obtained by difference from the mass balance. The LHV (lower heating value) of gas products were calculated based on the yield and lower heating values of $\mathrm{CO}, \mathrm{H}_{2}, \mathrm{CH}_{4}$ and $\mathrm{C}_{2} \mathrm{H}_{6}$ reported in Ref. [31]. Finally, after each experiment, the reactor was cleaned by alcohol to eliminate any tar deposit on the walls. Each run was repeated at least 3 times for better accuracy, and the uncertainty on repeatability was always less than $5 \%$.

\section{Results and discussion}

\subsection{Combined effects of temperature and HM}

\subsubsection{Final product distribution at different temperatures}

Product yields from raw and impregnated willow pyrolysis under different temperatures are presented in Fig. 2. For raw willow pyrolysis, the char yield significantly decreases from $25.77 \%$ to $10.27 \%$ when temperature increases from 600 to $1600{ }^{\circ} \mathrm{C}$ (Fig. 2a), and the liquid yield noticeably decreases from $63.43 \%$ to $42.73 \%$ as indicated in Fig. 2b, while the gas yield increases from $10.8 \%$ to $47.0 \%$ as depicted in Fig. 2c. As the temperature rises from 600 to $800^{\circ} \mathrm{C}$, the increase in the gas yield is mainly compensated by the decrease in the char yield. It is due to volatile formation reactions becoming more favorable during the competition with char formation reactions with increasing temperature [32]. The gas yield increases from $18.2 \%$ to $28.25 \%$ when temperature increases from 800 to $1000{ }^{\circ} \mathrm{C}$. In accordance, the char yield and liquid yield decrease by $4.1 \%$ and $5.9 \%$, respectively with temperature. It proves that the increase in gas yield is caused by inhibited char primary formation and enhanced by secondary degradation of tar vapors in this temperature range [33]. Then the gas yield slightly increases (with small decrease of char and liquid yield) at higher temperatures $\left(1000-1200-1400^{\circ} \mathrm{C}\right)$. We assume that heat transfer resistances through the pellet willow reduces the actual degradation temperature of the sample due to the resulting internal thermal gradient [33]. However, enhanced secondary reactions (such as cracking and polymerization) of tar vapors caused a rapid increase of gas yield and a decrease of liquid yield when temperature rises from 1400 to $1600^{\circ} \mathrm{C}$ [34]. The char yield slightly decrease, because the decreasing formation of primary char is compensated by the enhanced formation of secondary char from tar, which is also reported by Neves et al. [35].

The changing trend of pyrolysis product distribution with temperature was almost the same from raw willow and metalimpregnated willow. For impregnated willow pyrolysis, the char and liquid yield also decrease with increasing gas yield when temperature increased from 600 to $1600^{\circ} \mathrm{C}$. However, the presence of heavy metals (copper and nickel) leads to a decrease of the char yield compared with that of raw willow as shown in Fig. 2a. It is consistent with the results of Marwa et al. [36]. Copper restricts the final degradation of lignin into char, which caused a slight decrease of char yield obtained from copper impregnated willow [24]. For nickel impregnated willow pyrolysis, the char yield decreases from $21 \%$ to $9.9 \%$ with temperature rising from 600 to $1600^{\circ} \mathrm{C}$. According to Ref. [22] nickel could promote $\mathrm{C}-\mathrm{H}$ and $\mathrm{C}-\mathrm{O}$ bonds cleavage of char at high temperatures, thereby reducing the yield of char. The impact of heavy metal on pyrolysis liquid yield is two steps. The copper and nickel firstly promote the depolymerization of cellulose and hemicellulose resulting in more levoglucosan formation [22]. Furthermore, they substantially catalyze the secondary reactions of levoglucosan when the pyrolysis temperature is high enough. It results in higher liquid yields from impregnated willow than from raw willow when the pyrolysis temperature is not higher than $1000^{\circ} \mathrm{C}$ (Fig. 2 b). At temperature above $1000^{\circ} \mathrm{C}$, the high activity of copper and nickel catalysts promotes the cracking and reforming reactions of tar, which caused the decrease of liquid yield [37]. It then leads to the gas yield increase by $14.76 \%$ and $34.47 \%$ for copper and nickel impregnated willow pyrolysis at $1200^{\circ} \mathrm{C}$, respectively, compared to raw willow (Fig. 2c).

\subsubsection{Pyrolysis gas composition and LHVs at different temperatures}

The solar pyrolysis gas consists mainly of $\mathrm{H}_{2}, \mathrm{CO}$ and lower amounts of $\mathrm{CH}_{4}, \mathrm{CO}_{2}$ and $\mathrm{C}_{2}$ hydrocarbons, which distribution is different from conventional pyrolysis gas compositions [38]. $\mathrm{C}_{2} \mathrm{H}_{6}$ content shown in Fig. 3 mainly comes from tar decomposition, and it is not detected at $600{ }^{\circ} \mathrm{C}$ that is consistent with our previous study [30]. Increasing temperature to $1600{ }^{\circ} \mathrm{C}$ leads to $\mathrm{H}_{2}$ (Fig. 4) and CO (Fig. 5) yields increase from 0.16 to $12.1 \mathrm{~mol} / \mathrm{kg}$ of wood and 


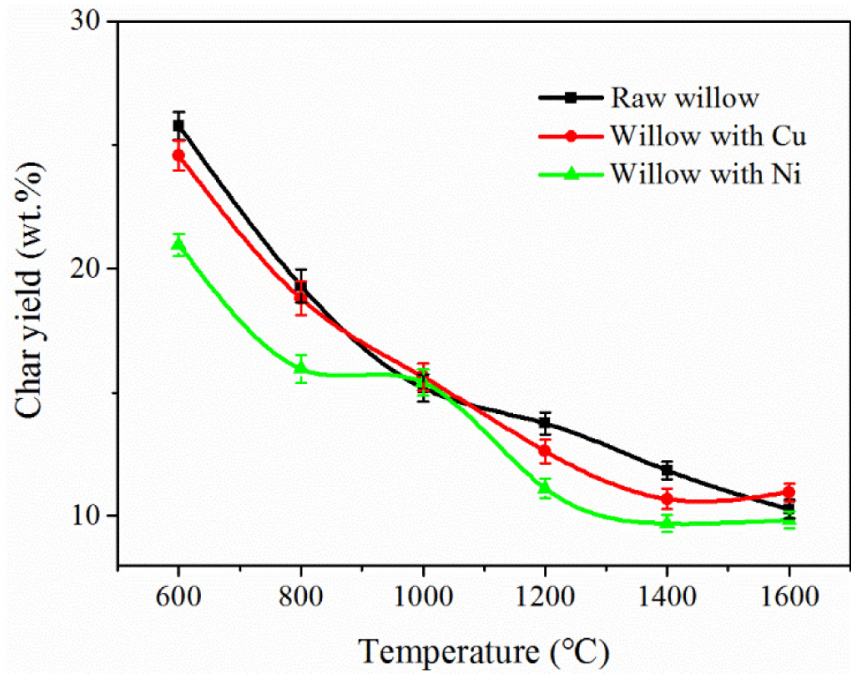

(a)

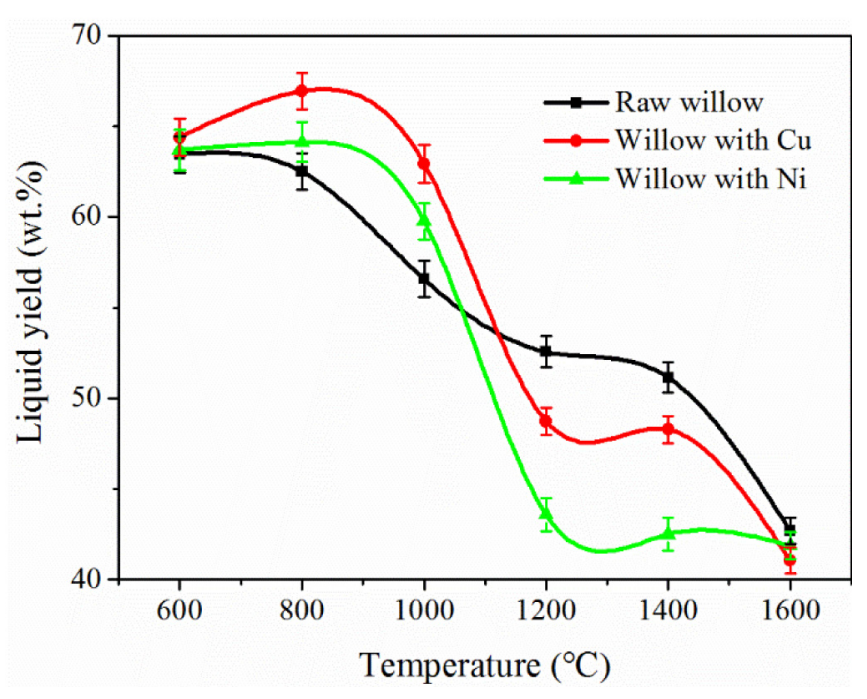

(b)

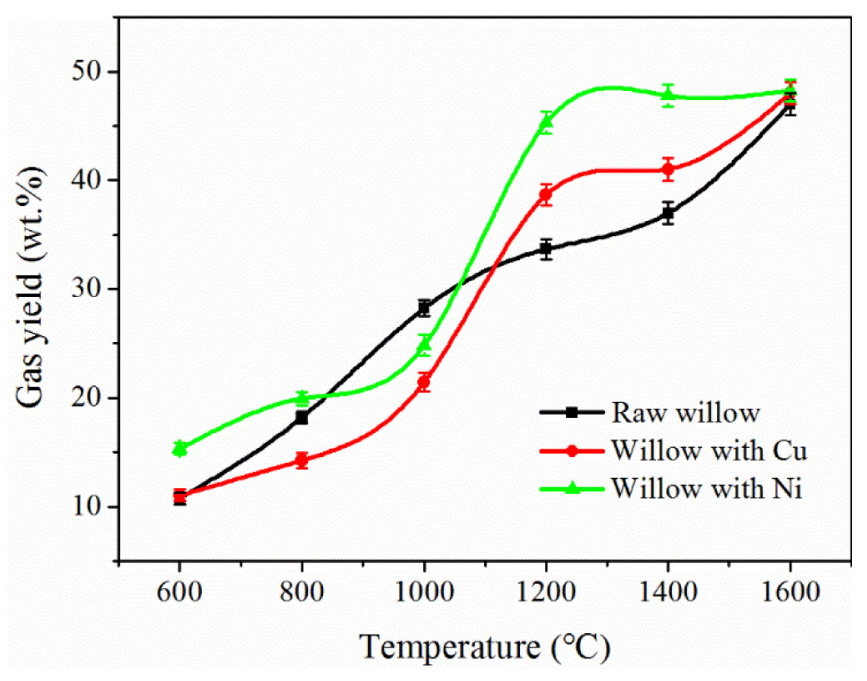

(c)

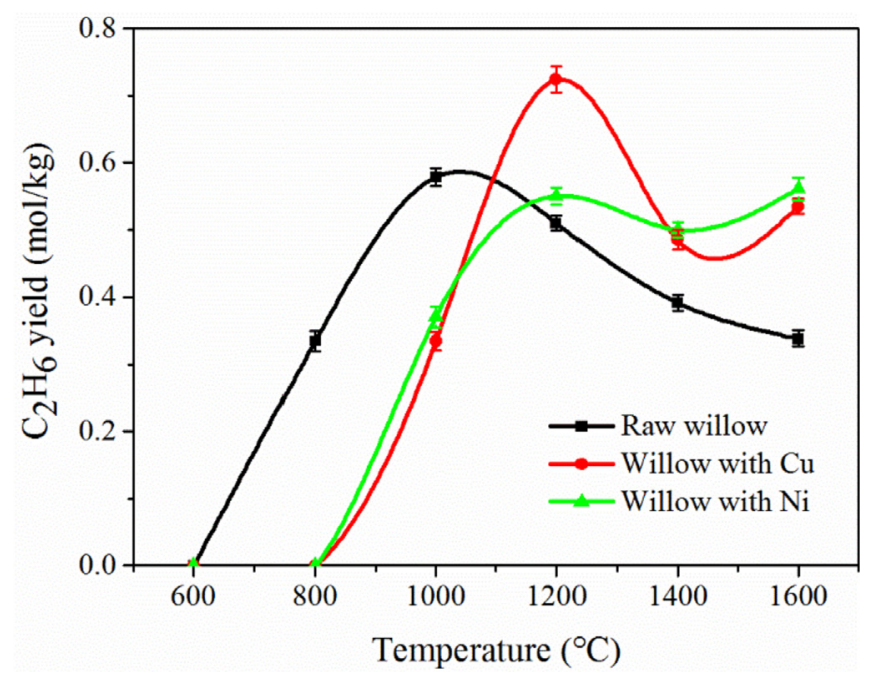

Fig. 3. Combined effects of temperature and $\mathrm{HM}$ on solar pyrolysis $\mathrm{C}_{2} \mathrm{H}_{6}$ yield.

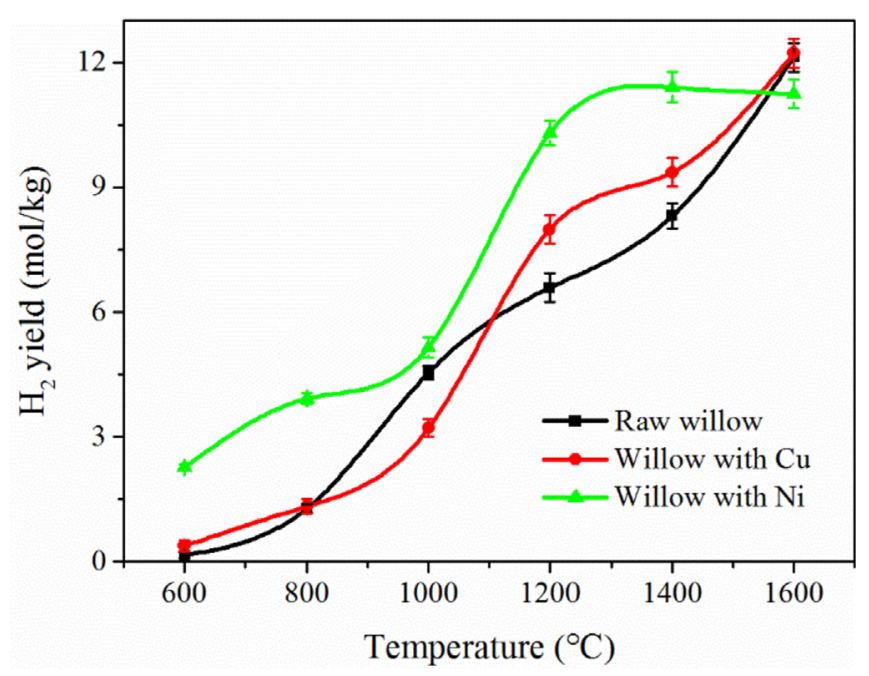

Fig. 4. Combined effects of temperature and $\mathrm{HM}$ on solar pyrolysis $\mathrm{H}_{2}$ yield.

from 1.9 to $12.9 \mathrm{~mol} / \mathrm{kg}$ of wood, respectively. In particular, their yields presented a linear increase with temperature, which can be interpreted as an indicator for tar secondary reactions [34]. A large part of their production comes from the intra-particle tar cracking reaction [18]. CO formation was found to explain $50 \%-70 \%$ of tar secondary reactions [39]. While, $\mathrm{CO}_{2}$ yield firstly decreases from 1.14 to $0.72 \mathrm{~mol} / \mathrm{kg}$ of wood as temperature increased from 600 to $1400^{\circ} \mathrm{C}$ as indicated in Fig. 6. This result is attributed to the enhanced reverse Boudouard reaction [40]. The maximum $\mathrm{CO}_{2}$ yield of $1.15 \mathrm{~mol} / \mathrm{kg}$ of wood is attained at $1600^{\circ} \mathrm{C} . \mathrm{CO}_{2}$ yield increase arises from tar secondary reactions as it could account for up to $14 \%$ of tar conversion [34,38]. $\mathrm{CH}_{4}$ yield (Fig. 7) and $\mathrm{C}_{2} \mathrm{H}_{6}$ yield (Fig. 3) increased from 0.18 to $1.67 \mathrm{~mol} / \mathrm{kg}$ of wood and from 0 to $0.58 \mathrm{~mol} / \mathrm{kg}$ of wood with a temperature increasing from 600 to $1000^{\circ} \mathrm{C}$, respectively resulting from the tar cracking reaction [17]. However, they reduce to 1.43 and $0.34 \mathrm{~mol} / \mathrm{kg}$ of wood, respectively. It is mainly due to the enhancement of their own cracking reaction and steam reforming reaction as temperature increase

Fig. 2. Combined effects of temperature and HM on solar pyrolysis product distribution: (a) Char yield, (b) Liquid yield, and (c) Gas yield. 


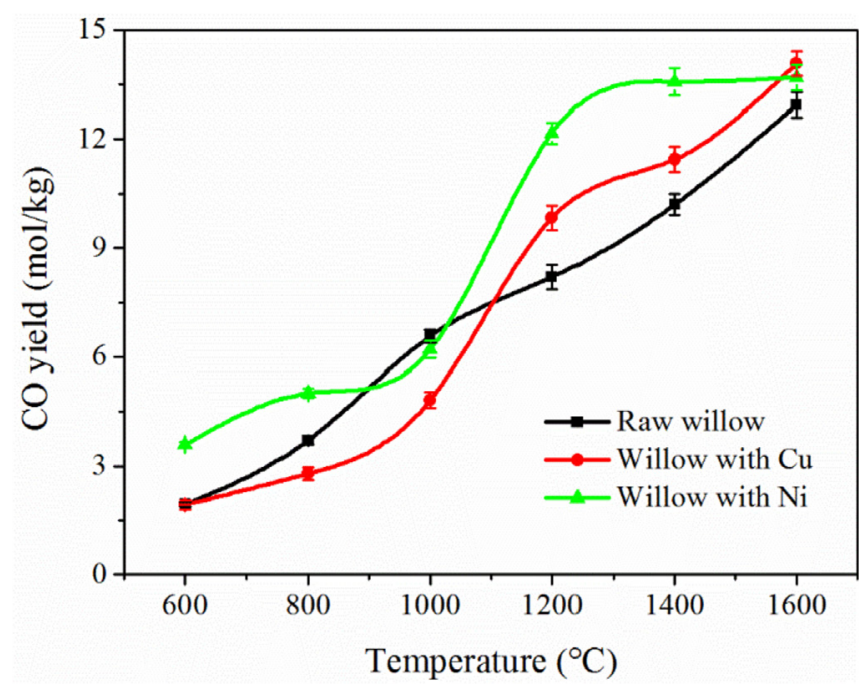

Fig. 5. Combined effects of temperature and HM on solar pyrolysis CO yield.

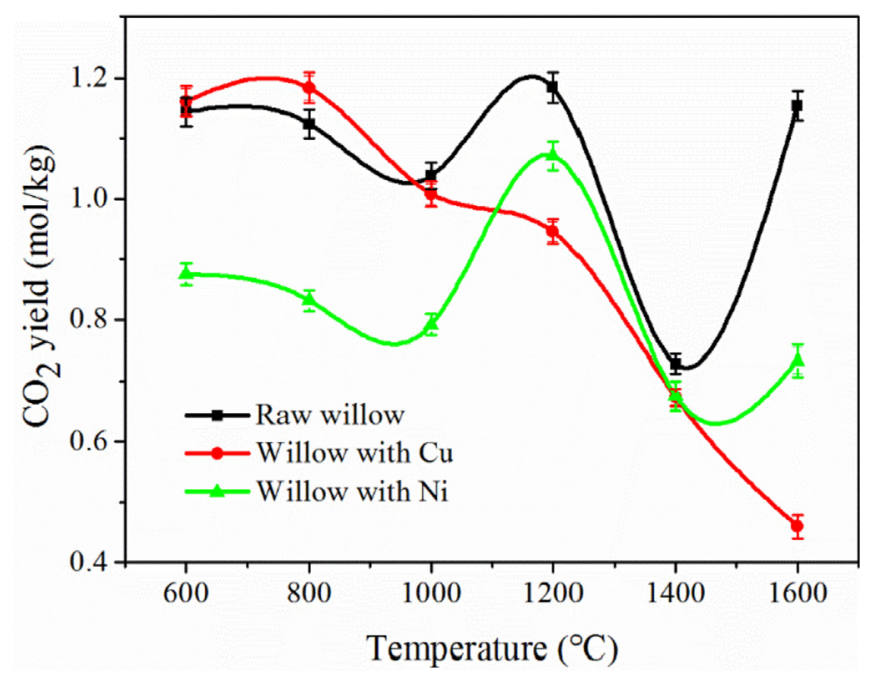

Fig. 6. Combined effects of temperature and $\mathrm{HM}$ on solar pyrolysis $\mathrm{CO}_{2}$ yield.

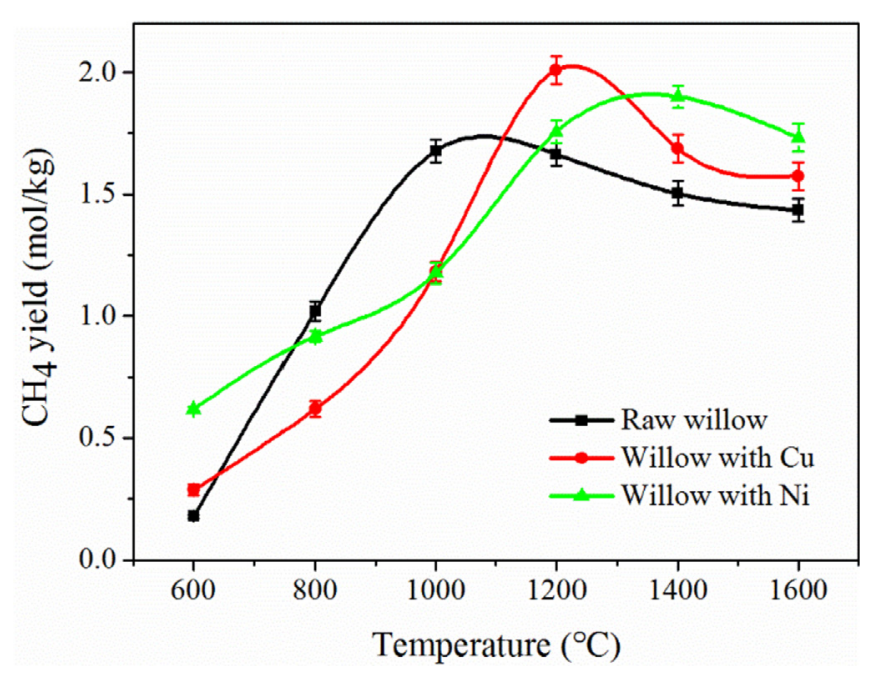

Fig. 7. Combined effects of temperature and $\mathrm{HM}$ on solar pyrolysis $\mathrm{CH}_{4}$ yield. from $1000^{\circ} \mathrm{C}$ to $1600^{\circ} \mathrm{C}$, which dominates their degradation mechanisms $[21,41]$.

The variation rule of pyrolysis gas composition with temperature is almost the same from raw willow and metal-impregnated willow. The presence of either copper or nickel results in an increase of the production of $\mathrm{H}_{2}, \mathrm{CO}, \mathrm{CH}_{4}$ and $\mathrm{C}_{2} \mathrm{H}_{6}$ while it decreases the $\mathrm{CO}_{2}$ yield when the pyrolysis temperature is higher than $1000^{\circ} \mathrm{C}$. In particular, Fig. 4 shows that the $\mathrm{H}_{2}$ yields for copperimpregnated willow and nickel-impregnated willow increases from 8 to $10.30 \mathrm{~mol} / \mathrm{kg}$ of wood to 12.2 and $11.24 \mathrm{~mol} / \mathrm{kg}$ of wood with a temperature increase from 1200 to $1600^{\circ} \mathrm{C}$, respectively. The increase of $\mathrm{H}_{2}$ yield is correlated with the increase of $\mathrm{CO}$ yields. It increases from 9.8 to $12.16 \mathrm{~mol} / \mathrm{kg}$ of wood to 14 and $13.70 \mathrm{~mol} / \mathrm{kg}$ of wood (Fig. 5). The increase of both $\mathrm{H}_{2}$ and $\mathrm{CO}$ yields are assumed to be mainly due to the cracking and reforming reactions of $\operatorname{tar}[18]$. Indeed, copper and nickel are used as efficient catalysts for tar decomposition reactions for producing $\mathrm{H}_{2}$ and $\mathrm{CO}[26,37]$. As found by other researchers, copper and nickel must be in the metal forms $\left(\mathrm{Cu}^{0}\right.$ and $\left.\mathrm{Ni}^{0}\right)$ for resulting in a catalytic effect on biomass pyrolysis reactions [22]. At low temperature, sulfur and oxygen have a high affinity with $\mathrm{Ni}$ and $\mathrm{Cu}$, respectively [36]. Therefore, a threshold temperature is required in biomass pyrolysis to induce the decomposition of nickel sulfide and copper oxide for enhancing their catalytic effect. The presence of copper slightly decreases $\mathrm{H}_{2}$ and $\mathrm{CO}$ yields at pyrolysis temperature not higher than $1000^{\circ} \mathrm{C}$. It is mainly interpreted as the inhibition effects of copper oxide on pyrolysis of biomass main components (cellulose and lignin) [37]. Although $\mathrm{Ni}$ and $\mathrm{Cu}$ could catalyze reforming reactions of $\mathrm{CH}_{4}$ and $\mathrm{C}_{2} \mathrm{H}_{6}$ and reduce their yields $[1,42]$. The enhanced cracking reactions of tar by $\mathrm{Ni}$ and Cu catalysts favore the formation of $\mathrm{CH}_{4}$ and $\mathrm{C}_{2} \mathrm{H}_{6}$ [3] as shown in Figs. 7 and 2. The slight increase of $\mathrm{CH}_{4}$ and $\mathrm{C}_{2} \mathrm{H}_{6}$ can be explained by the competition between formation reactions and reforming reactions that is dominated by the latter at temperature above $1000^{\circ} \mathrm{C}$. The reduction of $\mathrm{CO}_{2}$ yield illustrated in Fig. 6 is mainly due to $\mathrm{Cu}$ and Ni promoting the reverse Boudouard reaction $[25,42]$. Both metals' catalytic effect leads to almost the same tendency in solar pyrolysis gas composition with temperature. However, their influence is more obvious at temperature above $1000^{\circ} \mathrm{C}$ and the catalytic effect of $\mathrm{Ni}$ is more pronounced.

The LHVs (lower heating values) of the gas products significantly varied with temperature as a result of the gas composition change. The total gas product lower heating values of raw willow increased from 0.73 to $8.18 \mathrm{MJ} / \mathrm{kg}$ of wood, as the temperature increased from 600 to $1600^{\circ} \mathrm{C}$. This variation mainly resulted from the variation in the LHVs of $\mathrm{H}_{2}$ and CO. The total gas product LHVs of copper and nickel impregnated willow increased from 0.87 to $8.92 \mathrm{MJ} / \mathrm{kg}$ of wood and $2.05-8.74 \mathrm{MJ} / \mathrm{kg}$ of wood, respectively, as the temperature increased from 600 to $1600^{\circ} \mathrm{C}$. They significantly increased to $7.32 \mathrm{MJ} / \mathrm{kg}$ of wood and to $8.09 \mathrm{MJ} / \mathrm{kg}$ of wood as temperature increased to $1200^{\circ} \mathrm{C}$, respectively. Then, there was no significant change in the total LHVs at higher temperatures. This result indicates that the presence of either copper or nickel could lower optimum temperature as $1200^{\circ} \mathrm{C}$ at which for obtaining valuable combustible gas products.

\subsection{Combined effects of heating rate and $H M$}

\subsubsection{Final product distribution with different heating rate}

Product yields from solar pyrolysis of raw and impregnated willow at temperature of $1200^{\circ} \mathrm{C}$ under heating rates of $10^{\circ} \mathrm{C} / \mathrm{s}$ and $50{ }^{\circ} \mathrm{C} / \mathrm{s}$ are presented in Fig. 8. For raw willow pyrolysis, the gas yield ranges from $30.8 \%$ to $47 \%$ under heating of $10^{\circ} \mathrm{C} / \mathrm{s}$ and $50{ }^{\circ} \mathrm{C} / \mathrm{s}$ respectively. The liquid yield decreases from $54.5 \%$ to $42.7 \%$ as heating rate increased from $10^{\circ} \mathrm{C} / \mathrm{s}$ to $50^{\circ} \mathrm{C} / \mathrm{s}$. At the same time, the char yield decreases from $14.7 \%$ to $10.3 \%$. Fast heating rates favor 


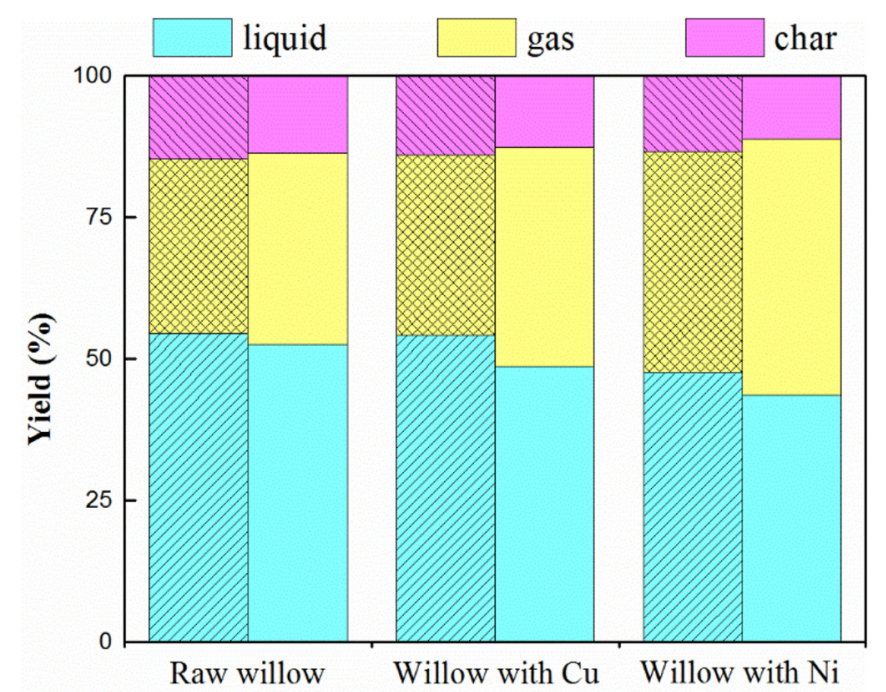

Fig. 8. Combined effects of heating rate and $\mathrm{HM}$ on solar pyrolysis product distribution: (shaded area for $10^{\circ} \mathrm{C} / \mathrm{s}$ ) and (solid area for $50^{\circ} \mathrm{C} / \mathrm{s}$ ).

the formation of volatiles versus char during biomass primary decomposition reactions $[43,44]$. Hence, the char yield decreases with a rise in heating rate. Furthermore, the pyrolysis temperature of $1200^{\circ} \mathrm{C}$ is much higher than the critical temperature of tar secondary reactions (about $500^{\circ} \mathrm{C}$ ) $[38,45]$. Consequently, an increase in the gas yield is caused by the tar secondary reactions. The changing trend of pyrolysis product yields with heating rate is almost the same for raw and impregnated willow as reported in Fig. 8. For copper impregnated willow pyrolysis, the gas yield increased from $31.8 \%$ to $48 \%$ when heating rate increased from 10 to $50{ }^{\circ} \mathrm{C} / \mathrm{s}$. At the same time, the liquid yield and char yield decreased from $54.1 \%$ to $41 \%$ and from $14 \%$ to $11 \%$, respectively. For nickelimpregnated willow pyrolysis, the gas yield increases from $39 \%$ to $48.3 \%$ with the heating rate rising from $10^{\circ} \mathrm{C} / \mathrm{s}$ to $50^{\circ} \mathrm{C} / \mathrm{s}$. At the same time, the liquid yield and char yield decrease from $41.6 \%$ to $41.9 \%$ and $13.4 \%-9.9 \%$, respectively. There is almost no difference found in the product distribution of raw and impregnated willow under different heating rates except for nickel-impregnated willow at $10^{\circ} \mathrm{C} / \mathrm{s}$. It is noted that gas yield and liquid yield significantly increase and decrease respectively for nickel impregnated willow in comparison with raw willow. Heating rate of $10^{\circ} \mathrm{C} / \mathrm{s}$ results in longer residence time of tar vapors [30]. Furthermore, the nickel was an active catalyst for tar cracking reactions [23]. Indeed, since the nickel is bundled to the wood matrix, liquid should pass through the nickel layer before evolving out of the wood [36]. During the process, the time of tar contact with nickel is enough for enhancing the activity of tar secondary reactions into gas products.

\subsubsection{Pyrolysis gas composition and LHVs with different heating} rates

The gas composition obtained from solar pyrolysis of raw and impregnated willow under different heating rates is illustrated in Fig. 9. For raw willow pyrolysis, the $\mathrm{H}_{2}, \mathrm{CO}$ and $\mathrm{CO}_{2}$ yields remarkably increase from 6.3 to $12.1 \mathrm{~mol} / \mathrm{kg}$ of wood, from 8.0 to $12.9 \mathrm{~mol} / \mathrm{kg}$ of wood and from 0.65 to $1.15 \mathrm{~mol} / \mathrm{kg}$ of wood respectively as the heating rate increased from 10 to $50{ }^{\circ} \mathrm{C} / \mathrm{s}$. Simultaneously, the $\mathrm{CH}_{4}$ and $\mathrm{C}_{2} \mathrm{H}_{6}$ yields slightly decrease from 1.7 to $1.4 \mathrm{~mol} / \mathrm{kg}$ of wood and 0.5 to $0.34 \mathrm{~mol} / \mathrm{kg}$ of wood, respectively. High heating rates favor the primary volatiles formation, which tend to crack into $\mathrm{H}_{2}$ and $\mathrm{CO}$ at $1200^{\circ} \mathrm{C}$ [46]. The $\mathrm{CO}_{2}$ increase is partly due to the inhibited reverse Boudouard reaction as its

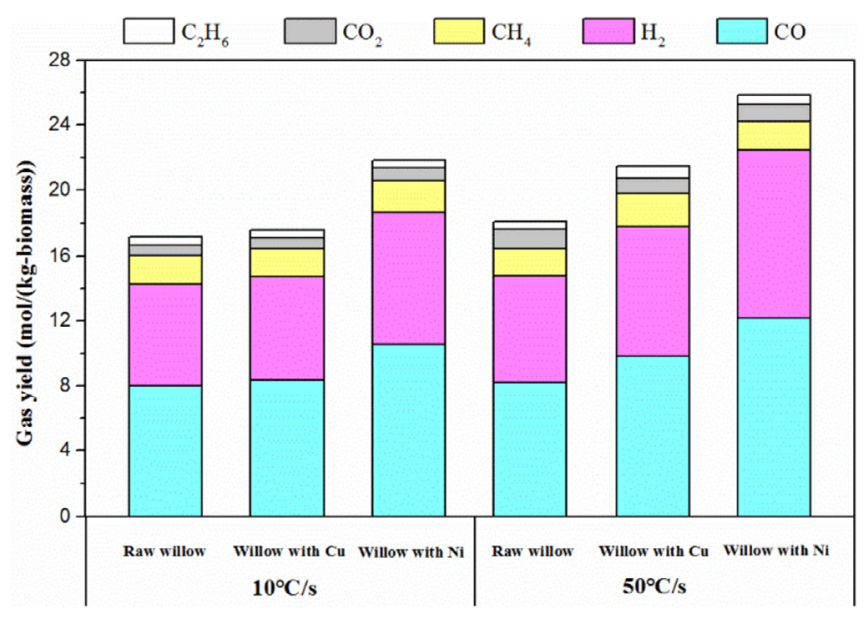

Fig. 9. Combined effects of heating rate and HM on solar pyrolysis gas composition.

residence time inside the char reduced under higher heating rate [47]. Although some $\mathrm{CH}_{4}$ and $\mathrm{C}_{2} \mathrm{H}_{6}$ are produced from the enhanced tar secondary reactions under high heating rates, their own cracking reaction is remarkably enhanced. The heavy metals change the trend of pyrolysis gas composition with heating rate (Fig. 9). Among them, $\mathrm{CO}_{2}$ yields for pyrolysis of copperimpregnated willow and nickel-impregnated willow decreased from 0.68 to $0.46 \mathrm{~mol} / \mathrm{kg}$ of wood and 0.79 to $0.73 \mathrm{~mol} / \mathrm{kg}$ of wood with increasing heating rate, respectively. Under a heating rate of $10^{\circ} \mathrm{C} / \mathrm{s}$, the gas composition is almost the same for raw and copperimpregnated willow. While for nickel-impregnated willow pyrolysis, the $\mathrm{H}_{2}$ and $\mathrm{CO}$ yields increase to 8.16 and $10.53 \mathrm{~mol} / \mathrm{kg}$ of wood in comparison with raw willow, respectively. This finding agrees well with the nickel effect on product distribution indicated above. It also fits well with previous results indicationg that nickel favored syngas production during cellulose pyrolysis [42]. Nickel can act as catalyst in pyrolysis and promote the dehydrogenation of benzene rings and cracking of carboxyl groups for $\mathrm{H}_{2}$ and $\mathrm{CO}$ formation $[28,48]$. Under a heating rate of $50^{\circ} \mathrm{C} / \mathrm{s}$, the presence of copper and nickel significantly decrease $\mathrm{CO}_{2}$ yields. It is mainly due to the higher reactivity of char obtained at a heating rate of $50{ }^{\circ} \mathrm{C} / \mathrm{s}$ [44]. In addition, the impregnated metals catalyze the gasification reactions with $\mathrm{CO}_{2}$, which leads to the reducing of $\mathrm{CO}_{2}$ yield [49]. The catalytic effect of both copper and nickel leads to the same tendency in the solar pyrolysis gas product yields with heating rate. However, the catalytic effect of nickel is more obvious: a 60\% decrease in $\mathrm{CO}_{2}$ production with nickel versus a $36 \%$ decrease with copper is observed.

The total gas product lower heating values of raw willow slightly increased from 5.88 to $5.95 \mathrm{MJ} / \mathrm{kg}$ of wood as the heating rate increased from 10 to $50^{\circ} \mathrm{C} / \mathrm{s}$. At the same time, the total gas product LHVs of copper and nickel impregnated willow increased from 5.93 to $7.33 \mathrm{MJ} / \mathrm{kg}$ of wood and $7.09-8.09 \mathrm{MJ} / \mathrm{kg}$ of wood, respectively. This increase was primarily due to $\mathrm{CO}, \mathrm{H}_{2}$, and $\mathrm{CH}_{4} \mathrm{LHV}$ variations. This result indicates that the heating rate effect on obtaining valuable combustible gas products is enhanced by the presence of either copper or nickel.

\section{Future perspectives}

The perspectives for solar pyrolysis technology is to develop a MW-scale commercial unit operating in continuous mode. This unit can used either the moving reacting-front concept (the reactant is pushed continuously at the focal point and the char separated by gravity), a fluidized bed or a molten salt reactor. Molten salt reactor 
allows the heat to be quickly transferred to raw materials and run stably even under solar energy transients, which can retract HMs from contaminated biomass and retain in molten salt. Unique features of solar reactor include the direct control of reactor temperature, heating rate and solids residence time. The reactor is designed to operate over a range of biomass HMs contents.

\section{Conclusion}

Experimental results on solar pyrolysis of metal-impregnated biomass indicate that the yields of char and liquid decrease with pyrolysis temperature and heating rate, while the gas yield significantly increases for raw willow pyrolysis. A threshold temperature of $1000{ }^{\circ} \mathrm{C}$ is required with impregnated willow pyrolysis to make sure copper and nickel catalytic effects on promoting the cracking and reforming reactions of tar. Then at $1200^{\circ} \mathrm{C}$ the gas yields from copper and nickel-impregnated willow pyrolysis increase by $14.76 \%$ and $34.47 \%$, respectively, compared with raw willow. In particular, the $\mathrm{H}_{2}$ and $\mathrm{CO}$ production resulting from nickel-impregnated willow solar pyrolysis are higher than from raw willow (10.30 and $12.16 \mathrm{~mol} / \mathrm{kg}$ of wood versus 6.60 and $8.20 \mathrm{~mol} / \mathrm{kg}$ of wood) in case of fast pyrolysis $\left(50^{\circ} \mathrm{C} / \mathrm{s}\right)$. Under a heating rate of $10^{\circ} \mathrm{C} / \mathrm{s}$, the gas composition is almost the same for raw and copper impregnated willow. While for nickel impregnated willow pyrolysis, the $\mathrm{H}_{2}$ and CO yields increase from 6.28 to 7.99 to 8.16 and $10.53 \mathrm{~mol} / \mathrm{kg}$ of wood in comparison with raw willow, respectively. Both metals' catalytic effect leads to almost the same tendency in gas composition and LHVs with temperature or heating rate during solar pyrolysis. However, their influence is more obvious at temperature above $1000^{\circ} \mathrm{C}$ and a heating rate of $50^{\circ} \mathrm{C} / \mathrm{s}$. In addition, the catalytic effect of $\mathrm{Ni}$ is more pronounced.

\section{Declaration of interests}

The authors declare that they have no known competing financial interests or personal relationships that could have appeared to influence the work reported in this paper.

\section{Acknowledgement}

This work was supported by French "Investments for the future" program managed by the National Agency for Research under contract ANR-10-LABX-22-01 (Labex SOLSTICE) and award number “ANR-10-EQPX-49-SOCRATE” (Equipex SOCRATE).

\section{References}

[1] Li R, Huang H, Wang JJ, Liang W, Gao P, Zhang Z, Xiao R, Zhou B, Zhang X Conversion of $\mathrm{Cu}(\mathrm{II})$-polluted biomass into an environmentally benign $\mathrm{Cu}$ nanoparticles-embedded biochar composite and its potential use on cyanobacteria inhibition. J Clean Prod 2019;216:25-32.

[2] He J, Strezov V, Kan T, Weldekidan H, Asumadu-Sarkodie S, Kumar R. Effect of temperature on heavy metal (loid) deportment during pyrolysis of Avicennia marina biomass obtained from phytoremediation. Bioresour Technol 2019;278:214-22.

[3] Liu W, Li W, Jiang H, Yu H. Fates of chemical elements in biomass during its pyrolysis. Chem Rev 2017:117(9):6367-98.

[4] Nzihou A, Stanmore B. The fate of heavy metals during combustion and gasification of contaminated biomass-A brief review. J Hazard Mate 2013:256:56-66.

[5] Lievens C, Carleer R, Cornelissen T, Yperman J. Fast pyrolysis of heavy metal contaminated willow: influence of the plant part. Fuel 2009;88(8):1417-25.

[6] Zhang X, Laubie B, Houzelot V, Plasari E, Echevarria G, Simonnot M. Increasing purity of ammonium nickel sulfate hexahydrate and production sustainability in a nickel phytomining process. Chem Eng Res Des 2016;106:26-32.

[7] Bert V, Allemon J, Sajet P, Dieu S, Papin A, Collet S, Gaucher R, Chalot M, Michiels B, Raventos C. Torrefaction and pyrolysis of metal-enriched poplars from phytotechnologies: effect of temperature and biomass chlorine content on metal distribution in end-products and valorization options. Biomass Bioenergy 2017;96:1-11
[8] Huang H, Yao W, Li R, Ali A, Du J, Guo D, Xiao R, Guo Z, Zhang Z, Awasthi MK. Effect of pyrolysis temperature on chemical form, behavior and environmental risk of $\mathrm{Zn}, \mathrm{Pb}$ and $\mathrm{Cd}$ in biochar produced from phytoremediation residue. Bioresour Technol 2018;249:487-93.

[9] Koppolu L, Clements LD. Pyrolysis as a technique for separating heavy metals from hyperaccumulators. Part 1: preparation of synthetic hyperaccumulator biomass. Biomass Bioenergy 2003;24:69-79. PII S0961-9534(02)00074-01.

[10] Koppolu L, Agblevor FA, Clements LD. Pyrolysis as a technique for separating heavy metals from hyperaccumulators. Part II: lab-scale pyrolysis of synthetic hyperaccumulator biomass. Biomass Bioenergy 2003;25(6):651-63.

[11] Koppolu L, Prasad R, Clements LD. Pyrolysis as a technique for separating heavy metals from hyperaccumulators. Part III: pilot-scale pyrolysis of synthetic hyperaccumulator biomass. Biomass Bioenergy 2004;26(5):463-72.

[12] Al Chami Z, Amer N, Smets K, Yperman J, Carleer R, Dumontet S, Vangronsueld J. Evaluation of flash and slow pyrolysis applied on heavy metal contaminated Sorghum bicolor shoots resulting from phytoremediation. Biomass Bioenergy 2014;63:268-79.

[13] Stals M, Thijssen E, Vangronsveld J, Carleer R, Schreurs S, Yperman J. Flash pyrolysis of heavy metal contaminated biomass from phytoremediation: influence of temperature, entrained flow and wood/leaves blended pyrolysis on the behaviour of heavy metals. J Anal Appl Pyrolysis 2010;87(1):1-7.

[14] Dong J, Chi Y, Tang Y, Ni M, Nzihou A, Weiss-Hortala E, Huang Q. Partitioning of heavy metals in municipal solid waste pyrolysis, gasification, and incineration. Energy Fuels 2015;29(11):7516-25.

[15] Syc M, Pohorely M, Jeremias M, Vosecky M, Kamenikova P, Skoblia S, Svoboda K, Puncochar M. Behavior of heavy metals in steam fluidized bed gasification of contaminated biomass. Energy Fuels 2011;25(5):2284-91.

[16] Zeng K, Gauthier D, Soria J, Mazza G, Flamant G. Solar pyrolysis of carbonaceous feedstocks: a review. Sol Energy 2017;156(SI):73-92.

[17] Zeng K, Gauthier D, Lu J, Flamant G. Parametric study and process optimization for solar pyrolysis of beech wood. Energy Convers Manag 2015;106: 987-98.

[18] Zeng K, Gauthier D, Li R, Flamant G. Combined effects of initial water content and heating parameters on solar pyrolysis of beech wood. Energy 2017;125: $552-61$.

[19] Schaffner B, Hoffelner W, Sun HY, Steinfeld A. Recycling of hazardous solid waste material using high-temperature solar process heat. 1. Thermodynamic analysis. Environ Sci Technol 2000;34(19):4177-84.

[20] Schaffner B, Meier A, Wuillemin D, Hoffelner W, Steinfeld A. Recycling of hazardous solid waste material using high-temperature solar process heat. 2. Reactor design and experimentation. Environ Sci Technol 2003·37(1):165-70.

[21] Zeng K, Gauthier D, Doan PM, Weiss-Hortala E, Nzihou A, Flamant G. Characterization of solar fuels obtained from beech wood solar pyrolysis. Fuel 2017:188:285-93.

[22] Nzihou A, Stanmore B, Lyczko N, Minh DP. The catalytic effect of inherent and adsorbed metals on the fast/flash pyrolysis of biomass: a review. Energy 2019; $170: 326-37$

[23] Eibner S, Broust F, Blin J, Julbe A. Catalytic effect of metal nitrate salts during pyrolysis of impregnated biomass. J Anal Appl Pyrolysis 2015;113:143-52.

[24] Xing S, Yuan H, Huhetaoli, Qi Y, Lv P, Yuan Z, Chen Y. Characterization of the decomposition behaviors of catalytic pyrolysis of wood using copper and potassium over thermogravimetric and Py-GC/MS analysis. Energy 2016;114: 634-46.

[25] Liu W, Tian K, Jiang H, Zhahg X, Ding H, Yu H. Selectively improving the bio-oil quality by catalytic fast pyrolysis of heavy-metal-polluted biomass: take copper (Cu) as an example. Environ Sci Technol 2012;46(14):7849-56.

[26] Richardson Y, Blin J, Volle G, Motuzas J, Julbe A. In situ generation of Ni metal nanoparticles as catalyst for $\mathrm{H} 2$-rich syngas production from biomass gasification. Appl Catal Gen 2010;382(2):220-30.

[27] Richardson Y, Motuzas J, Julbe A, Volle G, Blin J. Catalytic investigation of in situ generated Ni metal nanoparticles for tar conversion during biomass pyrolysis. J Phys Chem C 2013;117(45):23812-31.

[28] Bru K, Blin J, Julbe A, Volle G. Pyrolysis of metal impregnated biomass: an innovative catalytic way to produce gas fuel. J Anal Appl Pyrolysis 2007;78(2): 291-300.

[29] Liu Y, Guo F, Li X, Li T, Peng K, Guo C, Chang J. Catalytic effect of iron and nickel on gas formation from fast biomass pyrolysis in a microfluidized bed reactor: a kinetic study. Energy Fuels 2017;31(11):12278-87.

[30] Zeng K, Gauthier D, Li R, Flamant G. Solar pyrolysis of beech wood: effects of pyrolysis parameters on the product distribution and gas product composition. Energy 2015;93(2):1648-57.

[31] Fossum M, Beyer RV. Co-combustion of natural gas and low calorific value gas from biomass. SINTEF Energy Res 1998. Report prepared for IEA Biomass Gasification Activity, Trondheim.

[32] Di Blasi C. Modeling chemical and physical processes of wood and biomass pyrolysis. Prog Energy Combust Sci 2008;34(1):47-90.

[33] Di Blasi C. Combustion and gasification rates of lignocellulosic chars. Prog Energy Combust Sci 2009;35(2):121-40.

[34] Morf P, Hasler P, Nussbaumer T. Mechanisms and kinetics of homogeneous secondary reactions of tar from continuous pyrolysis of wood chips. Fuel 2002;81:843-53.

[35] Neves D, Thunman H, Matos A, Tarelho L, Gomez-Barea A. Characterization and prediction of biomass pyrolysis products. Prog Energy Combust Sci 2011;37(5):611-30.

[36] Said M, Cassayre L, Dirion J, Nzihou A, Joulia X. Influence of nickel on biomass 
pyro-gasification: coupled thermodynamic and experimental investigations. Ind Eng Chem Res 2018;57(30):9788-97.

[37] Yuan H, Xing S, Huhetaoli, Lu T, Chen Y. Influences of copper on the pyrolysis process of demineralized wood dust through thermogravimetric and Py-GC/ MS analysis. J Anal Appl Pyrolysis 2015;112:325-32.

[38] Aysu T, Kucuk MM. Biomass pyrolysis in a fixed-bed reactor: effects of pyrolysis parameters on product yields and characterization of products. Energy 2014;64:1002-25.

[39] Boroson ML, Howard JB, Longwell JP, Peters AW. Products yields and kinetics from the vapor phase cracking of wood pyrolysis tars. AIChE J 1989;35:120-8.

[40] Septien S, Valin S, Dupont C, Peyrot M, Salvador S. Effect of particle size and temperature on woody biomass fast pyrolysis at high temperature (10001400 degrees C). Fuel 2012;97:202-10.

[41] Lopez-Gonzalez D, Fernandez-Lopez M, Valverde JL, Sanchez-Silva L. Pyrolysis of three different types of microalgae: kinetic and evolved gas analysis. Energy 2014;73:33-43.

[42] Zhao M, Florin NH, Harris AT. The influence of supported Ni catalysts on the product gas distribution and $\mathrm{H} 2$ yield during cellulose pyrolysis. Appl Catal B Environ 2009;92(1-2):185-93.
[43] Sulaiman F, Abdullah N. Optimum conditions for maximising pyrolysis liquids of oil palm empty fruit bunches. Energy 2011:36(5):2352-9.

[44] Zeng K, Doan PM, Gauthier D, Weiss-Hortala E, Nzihou A, Flamant G. The effect of temperature and heating rate on char properties obtained from solar pyrolysis of beech wood. Bioresour Technol 2015;182:114-9.

[45] Chhiti Y, Salvador S, Commandre J, Broust F. Thermal decomposition of biooil: focus on the products yields under different pyrolysis conditions. Fuel 2012;102:274-81.

[46] Williams PT, Besler S. The influence of temperature and heating rate on the slow pyrolysis of biomass. Renew Energy 1996;7:233-50.

[47] Beattie WH, Berjoan R, Coutures J-P. High-temperature solar pyrolysis of coal. Sol Energy 1983;31:137-43.

[48] Collard F, Blin J, Bensakhria A, Valette J. Influence of impregnated metal on the pyrolysis conversion of biomass constituents. J Anal Appl Pyrolysis 2012;95: 213-26.

[49] Said M, Cassayre L, Dirion J, Joulia X, Nzihou A. Effect of nickel impregnation on wood gasification mechanism. Waste Biomass Valorization 2017;8(8): 2843-52. 